Vol. 18 (2009): 347-365.

\title{
Field biomass as global energy source
}

\author{
Kaija Hakala, Markku Kontturi and Katri Pahkala \\ MTT Agrifood Research Finland, Plant Production Research, FI-31600 Jokioinen, Finland, \\ e-mail: firstname.lastname@mtt.fi
}

\begin{abstract}
Current (1997-2006) and future (2050) global field biomass bioenergy potential was estimated based on FAO (2009) production statistics and estimations of climate change impacts on agriculture according to emission scenario B1 of IPCC. The annual energy potential of raw biomass obtained from crop residues and bioenergy crops cultivated in fields set aside from food production is at present $122-133 \mathrm{EJ}, 86-93 \mathrm{EJ}$ or 47-50 EJ, when a vegetarian, moderate or affluent diet is followed, respectively. In 2050, with changes in climate and increases in population, field bioenergy production potential could be 101-110 EJ, 57-61 EJ and 44-47 EJ, following equivalent diets. Of the potential field bioenergy production, 39-42 EJ now and $38-41$ EJ in 2050 would derive from crop residues. The residue potential depends, however, on local climate, and may be considerably lower than the technically harvestable potential, when soil quality and sustainable development are considered. Arable land could be used for bioenergy crops, particularly in Australia, South and Central America and the USA. If crop production technology was improved in areas where environmental conditions allow more efficient food production, such as the former Soviet Union, large areas in Europe could also produce bioenergy in set aside fields. The realistic potential and sustainability of field bioenergy production are discussed.
\end{abstract}

Key-words: biomass, energy, food, global, potential, residues

\section{Introduction}

The global surface temperature has increased during the last century (1850-1899 to 2001-2005) by an average of $0.76^{\circ} \mathrm{C}$. The warming has been especially rapid during the last decade, the period 1995-2006 being the warmest ever recorded (IPCC 2007a). The observed increase in average global temperature is mostly due to increases in anthropogenic greenhouse gas concentrations, the 
Hakala, K. et al. Field biomass as global energy source

most important of which is $\mathrm{CO}_{2}$ (IPCC 2007a). With increases in global temperatures, the entire global climate system has changed: precipitation has increased in northern Europe, eastern parts of North and South America and northern and central Asia, while it has decreased across the Sahel, the Mediterranean, southern Africa and parts of southern Asia (IPCC 2007a). Because of the differences in regional changes, the effects on agricultural production differ in different parts of the world. In general, small increases in temperature (under $3{ }^{\circ} \mathrm{C}$ ) will improve agricultural production at high latitudes (e.g. northern Europe, North America), but increases in temperatures as small as $1-2{ }^{\circ} \mathrm{C}$ would worsen conditions at low latitudes (India, China, dry areas in Africa) (IPCC 2007b). On general, increases of temperatures higher than 3 ${ }^{\circ} \mathrm{C}$ are projected to decrease global food production and food production at high latitudes will also be threatened, depending on the region (IPCC 2007b). At the same time, populations in areas with the highest vulnerability to climate change are projected to increase most (IPCC 2007b, United Nations 2007).

Because of the obvious severity of the impacts of climate change, governments around the globe have agreed on measures to reduce greenhouse gas emissions. The best known agreement, the Kyoto protocol, was first adopted in 1997, and by the end of 2008 had been ratified by 177 countries and the European Community. It entered into force on 16 February 2005. Industrialized countries agreed on reducing (relative to year 1990) their greenhouse gas emissions by an average of $5 \%$ from the 1990 emission levels, during the period 2008-2012 (United Nations 1998), with 8\% reduction assigned for EU (UNFCCC).

Greenhouse gas emissions decreased by $7.7 \%$ in the EU-27 countries between 1990 and 2006. However, in the EU-15 group originally committed to the Kyoto protocol, the decrease was only $2.7 \%$. The projections for 2010 suggest, however, that the $8 \%$ target reductions will be met during the period 2008-2012, partly through use of the Kyoto mechanisms such as joint implementation or adoption of clean technology (EEA 2008). An important way to reduce greenhouse gas emis- sions is to use renewable energy sources. Sunlight, water flows, wind and biomass from forests and fields have always been used for different energy needs. Currently renewable energy sources make up only about $18 \%$ of all consumed energy, and traditional biomass energy 13\% (REN21 2008). Thus, in 2004, when the global primary energy demand was calculated to be 464 EJ (Sims et al. 2007) the share of biomass energy in this figure was $44.6 \mathrm{EJ}$ (altogether 9.6\%), of which wood fuel comprised $39 \mathrm{EJ}$, agro fuels $4.2 \mathrm{EJ}$ and municipal waste 1.1 EJ. However, the energy demand in 2050 will be about double compared to 2004 (baseline about $850 \mathrm{EJ}$ and policy scenario of 2 ${ }^{\circ} \mathrm{C}$ temperature increase about $810 \mathrm{EJ}$ ), and the assumed bioenergy potentials would be $270 \mathrm{EJ}$ (wood fuel 57 EJ and agro fuels 213 EJ) in 2050 (evaluated with the VTT version of the ETSAP TIAM energy system model described in Koljonen et al. 2009). To efficiently contribute to mitigation of climate change, EU has taken a further decision in December 2008, where the $27 \mathrm{EU}$ countries are committed to further cutting their greenhouse gas emissions by $20 \%$ (compared with the 1990 level), increasing the share of renewable energy sources to $20 \%$ of all energy needed, and cutting energy use by $20 \%$ by 2020 . In addition, $10 \%$ of transport fuel should originate from renewable sources by 2020 .

When biomass production potential for bioenergy has been considered on basis of soil and climatic suitability, the possible energy crop production values have ranged from $<100 \mathrm{EJ}$ to $>400$ EJ (Berndes et al. 2003, Hoogwijk et al. 2005), even reaching 648 EJ when all land suitable for biomass production is used efficiently (Wolf et al. 2003). With technological development, and development of infrastructure, the bioenergy production figures presented e.g. for Africa (Hoogwijk et al. 2005) could be reached. However, much less is actually being produced at the moment, not even enough food, with the percentage of undernourished people remaining high in Africa (FAO 2009). Thus, looking at the present field crop production values gives a more realistic picture of the crop production situation. Therefore, in the present simple survey based on FAO pro- 
Vol. 18 (2009): 347-365.

duction statistics (FAO 2009) we estimated the sufficiency of crop production at the moment and in the future (2050) and how much raw material for bioenergy, either as crop residues or specific bioenergy plants, could realistically be harvested from the field, taking into account the field area demand for food production. For the future we estimated how increases in population (United Nations 2007) and climate change would affect the production of field biomass energy. The world in this study is divided into 15 areas (Annex 1) according to the targets set by the umbrella project SEKKI, "The competitiveness of Finnish energy industry under developing climate policy" (Syri et al. 2008a). This project monitored the worldwide availability of energy now and in the future (2050), employing the global TIMES model (Syri et al. 2008b). The studied areas would normally be trading food among each other, but here they are for simplicity considered as independent units. For the future, the assumptions were that development will proceed according to the emission scenario B1 of IPCC (Nakicenovic et al. 2000, IPCC 2007a), that all arable land of the present day is used for field biomass production, and that field area does not increase. Emission scenario B1 was chosen, as efficient employment of renewable energy sources, including field bioenergy, aims at radical reductions of greenhouse gas emissions, as is also assumed in the B1 scenario of IPCC.

\section{Materials and methods}

\section{Applying scenarios of climate change effects on crop production}

Crop production data were derived from FAO (2009). The production data were from 1997 to 2006 and averages from that period were used in calculations of food production, availability of arable area for bioenergy crops production and production potential of crop residues for bioenergy. Emission scenario B1 was used as the basis for the future climate, centred on year 2050. The B1 scenario assumes reduced emissions and only about $2^{\circ} \mathrm{C}$ increase in global average temperature by 2100 , with about a $1.2-1.3{ }^{\circ} \mathrm{C}$ increase in temperatures by 2050 (Nakicenovic et al. 2000, IPCC 2007a). The scenario is optimistic, but emission reductions are possible, especially if renewable energy sources become the preferred source, as planned for the EU-27, for example.

In Europe (with the exception of the Mediterranean area) the impacts of climate change are expected to be rather small and mostly positive by 2050, if development proceeds according to emission scenario B1 (Parry et al. 2004, IPCC 2007b). However, factors other than climate change are predicted to influence crop production dramatically. Thus, through technological development and plant breeding etc., crop yields could increase 1.7- (WEU), 2- (EEU) or 4- (FSU) fold, compared with current yields (Olesen and Bindi 2002, Ewert et al. 2005). As scenarios involving breeding and technological development together with climate change effects are not available for all areas studied here, we follow the global scenarios of IPCC, interpreted by Parry et al. (2004) regarding changes in crop production under scenario B1 (multiplication coefficients in Annex 1). The changes (positive or negative) in production are relatively small (less than $10 \%$ ). However, as scenarios for technological development are available for WEU, EEU and FSU, and the climatic conditions also favour development in these areas, we considered the estimates of Olesen and Bindi (2002) and Ewert et al. (2005) for field crop production developments in these areas as well.

\section{Calculation of crop residue potential}

The theoretical crop residue potential was estimated using yield, yield dry matter (DM) content and harvest index (HI) of each individual crop species (Annex 2). HI describes the share of harvested yield of the total biomass of a crop on a DM basis. Based on published literature and our own results, a single harvest index was chosen per crop and 


\section{Hakala, K. et al. Field biomass as global energy source}

the theoretical residue potential was calculated as: $(1-\mathrm{HI}) \times$ yield DM) $/ \mathrm{HI}$. For calculation of the harvestable residue, or technical residue potential, the estimated biomass of the crop stubble left on the field as well as the residue lost through shedding of the straw material at harvest was reduced from the theoretical residue potential. For cereals, oil crops and pulses the stubble is normally $15-30 \mathrm{~cm}$ high, depending on crop and the harvesting conditions. According to Finnish research results, $15 \mathrm{~cm}$ barley (Hordeum vulgare L.) stubble represents about $27 \%$ of all straw biomass (Pahkala et al. 2007, Pahkala and Kontturi 2008). Studies of other cereals reached similar conclusions (Staniforth 1979). The technical residue potential in this study is thus a product of the theoretical potential reduced by $30 \%$ for cereals, oil crops and pulses, $25 \%$ for grain maize (Zea mays L.) (Graham et al. 2007), and 50\% for root crops including sugar beet (Beta vulgaris L. subsp. vulgaris). After determination of the technical crop residue potential of each individual species for the year 2006 (Table 1, Pahkala et al. 2009), the values were corrected according to the 10 year production averages (1997-2006) of the same crop groups (cereals, pulses, oil crops, root crops and sugar crops), and variation in residue potential was estimated according to the variation in production (Table 2). When crop residue production was estimated for the future (2050), the average technical residue potential values for 1997-2006 were corrected at group level for climate change effects (Annex 1). The resulting residue production figures for the future thus assume similar division of crop groups into individual crop species as at present. The energy value of each residue type was assumed to be $18 \mathrm{MJ} \mathrm{kg}^{-1} \mathrm{DM}$.

\section{Estimation of food sufficiency and availability of field for bioenergy crops}

Food sufficiency was estimated using the production statistics of FAO (2009). Grain equivalent (GE) values (on $\mathrm{kg}$ of wheat grain basis) were fitted for different crops, as described by Penning de Vries et al. (1997). In the calculation of GE, production quantities (averages of 1997-2006) of all cultivated crops listed in FAO statistics (FAO 2009) except temporary forage grasses were included in the total energy values for each of the 15 areas. Thus, in addition to cereals, pulses, oil crops, sugar crops and root crops, production of vegetables, fruits, nuts and fibre crops (hemp, flax, etc.) were also taken into account. Sufficiency of food production on arable land was then evaluated for each area for three different diets, vegetarian (GE usage $490 \mathrm{~kg}$ per capita per annum), moderate $(860 \mathrm{~kg})$ and affluent $(1535 \mathrm{~kg})$, using the United Nations population statistics. Estimation of food sufficiency in the future (2050) was based on United Nations estimations of population in the different areas (United Nations 2007) and estimations of changes in agricultural production (Parry et al. 2004) in the future (Annex 1). Before any of the areas were considered able to set aside field from food production, the GE required for each diet was doubled to cover yield fluctuations, storage losses (which can be substantial, particularly in developing countries) and other production uncertainties (Penning de Vries et al. 1997, Wolf et al. 2003). Food value of animal husbandry products relying solely on grazing was not taken into account, as data for calculations of productivity of permanent pastures was not available for all the studied areas. Also game and fish were excluded from the calculations.

Estimation of energy crop yields and energy values per hectare were done using average yields from 1997-2006 for each area, where enough land for energy crops was available. Energy crop species were chosen from typical crops grown or potentially grown in each area. The average yield levels (1997-2006) of the conventional grain/ seed crops and sugar cane were derived from FAO (2009) statistics, and the yields of special energy crops were taken from literature (Mischantus: Woods et al. 2006; reed canary grass: Pahkala et al. 2008; switchgrass: Schmer et al. 2008). The hypothesised share of the crop was used for assessing the total bioenergy of the crops (Table 3 ). For estimation of values in 2050, the effect of climate change was taken into account, as stated in Annex 1. 
Vol. 18 (2009): 347-365.

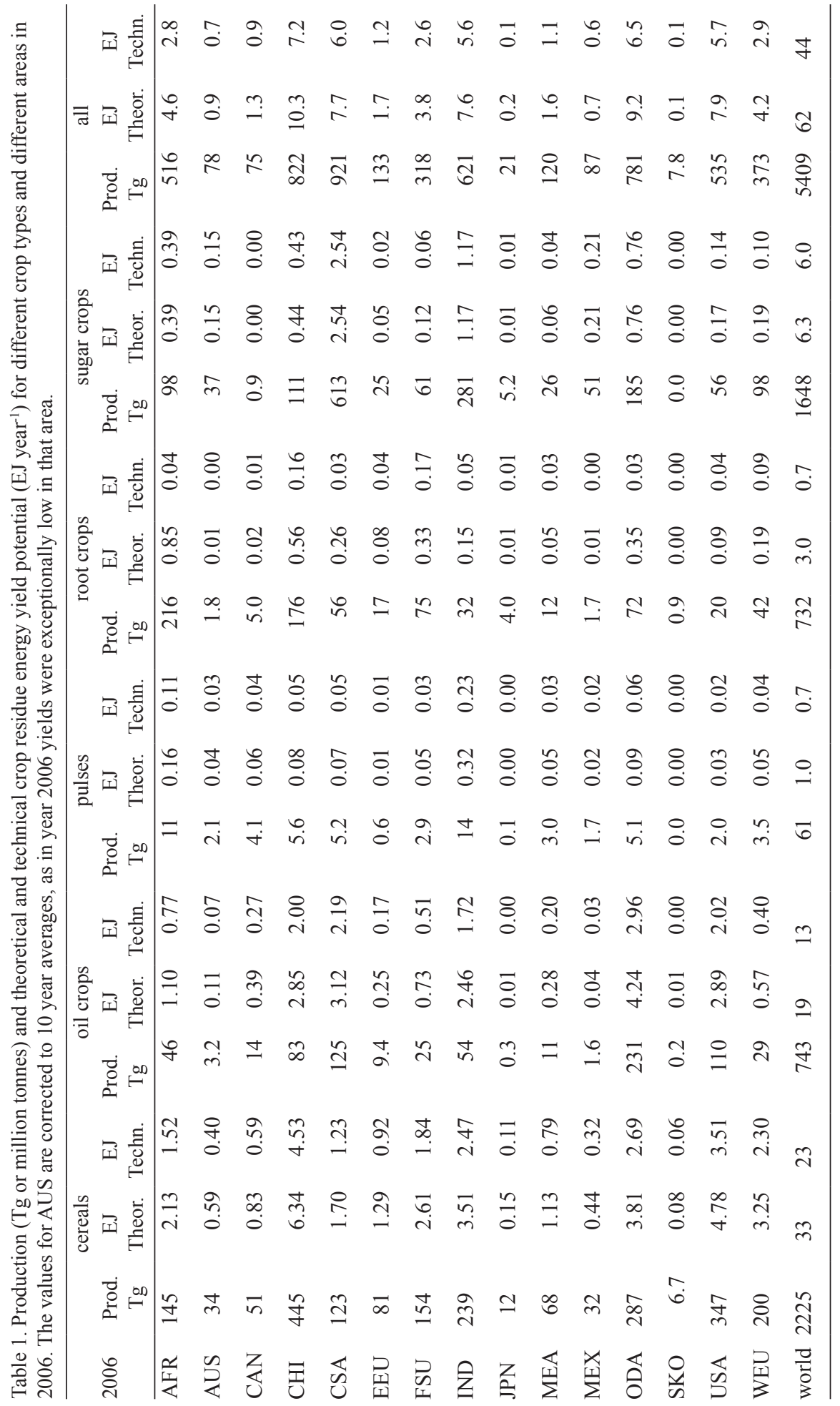




\section{AGRICULTURAL AND FOOD SCIENCE}

\section{Hakala, K. et al. Field biomass as global energy source}

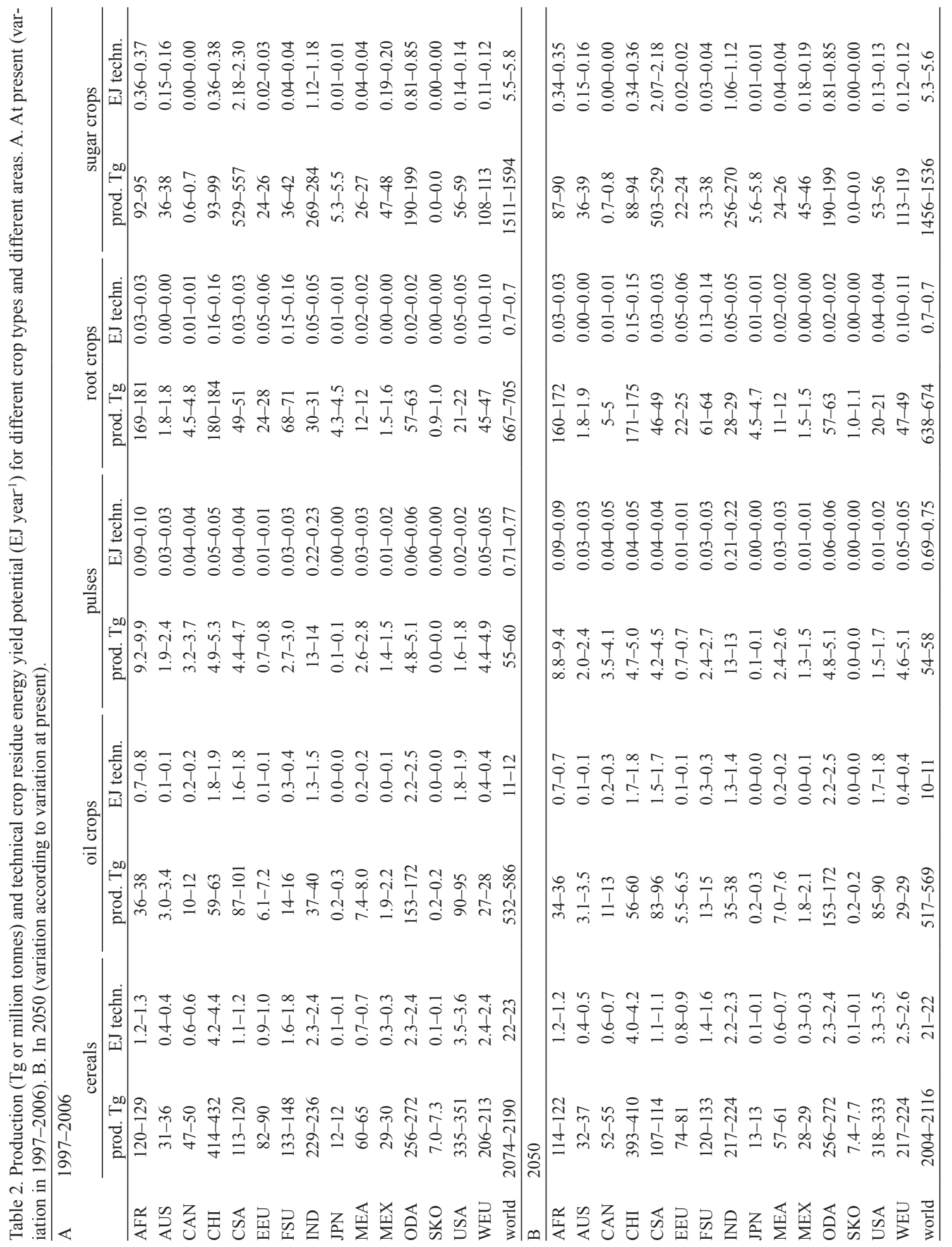


Vol. 18 (2009): 347-365.

Table 3. Energy crops and their energy values $\left(\mathrm{GJ} \mathrm{ha}^{-1}\right)$ for areas where arable land is likely to become available for biomass production for energy. At present: variation in average production in 1997-2006. In 2050, variation is assumed to be relatively the same as at present.

\begin{tabular}{|c|c|c|c|c|c|c|}
\hline Area & Crop & $\begin{array}{l}\text { Energy } \\
\text { content } \\
\mathrm{MJ} \mathrm{kg}^{-1}\end{array}$ & $\begin{array}{l}\text { Average bio- } \\
\text { mass yield (tn } \\
\text { ha }^{-1} \text { ) at present }\end{array}$ & $\begin{array}{l}\text { Share in } \\
\text { the area }\end{array}$ & $\begin{array}{l}\text { Average energy content } \\
\text { at present }\left(\mathrm{GJ} \mathrm{ha}^{-1}\right) \\
\text { in the area }\end{array}$ & $\begin{array}{l}\text { Average energy con- } \\
\text { tent in } 2050 \\
\left(\mathrm{GJ} \mathrm{ha}^{-1}\right) \text { in the area }\end{array}$ \\
\hline \multirow[t]{2}{*}{ AUS } & wheat & 18 & $2.5-3.0$ & 0.7 & $254-277$ & $261-284$ \\
\hline & sugar cane & 18 & $41.2-44.3$ & 0.3 & & \\
\hline \multirow[t]{3}{*}{ CAN } & rapeseed & 26 & $3.0-3.2$ & 0.3 & $100-108$ & $110-119$ \\
\hline & maize & 18 & $10.2-10.9$ & 0.3 & & \\
\hline & wheat & 18 & $3.6-3.9$ & 0.4 & & \\
\hline \multirow[t]{2}{*}{ CSA } & sugar cane & 18 & $32.4-33.6$ & 0.7 & $437-453$ & $416-431$ \\
\hline & soybean & 26 & $4.3-4.6$ & 0.3 & & \\
\hline \multirow[t]{4}{*}{ EEU } & reed canary grass & 18 & $3.0-7.0$ & 0.2 & $86-124$ & $77-112$ \\
\hline & miscanthus & 18 & $7.0-12.0$ & 0.2 & & \\
\hline & rapeseed & 26 & $4.5-5.0$ & 0.4 & & \\
\hline & sunflower & 26 & $2.5-2.9$ & 0.2 & & \\
\hline \multirow[t]{4}{*}{ FSU } & reed canary grass & 18 & $3.0-7.0$ & 0.1 & $43-54$ & $39-49$ \\
\hline & rapeseed & 26 & $2.2-2.5$ & 0.2 & & \\
\hline & sunflower & 26 & $1.8-1.9$ & 0.4 & & \\
\hline & barley & 18 & $2.3-2.5$ & 0.3 & & \\
\hline \multirow[t]{2}{*}{ MEX } & sugar cane & 18 & $36.1-36.7$ & 0.7 & $474-483$ & $450-459$ \\
\hline & soybean & 26 & $2.9-3.0$ & 0.3 & & \\
\hline \multirow[t]{3}{*}{ USA } & maize & 18 & $11.9-12.5$ & 0.5 & $264-308$ & $251-293$ \\
\hline & sugar cane & 18 & $36.2-37.8$ & 0.2 & & \\
\hline & switchgrass & 18 & $5.0-11.1$ & 0.3 & & \\
\hline \multirow[t]{4}{*}{ WEU } & reed canary grass & 18 & $3.0-7.0$ & 0.2 & $105-141$ & $111-148$ \\
\hline & miscanthus & 18 & $7.0-12.0$ & 0.2 & & \\
\hline & rapeseed & 26 & $6.5-6.8$ & 0.4 & & \\
\hline & sunflower & 26 & $3.1-3.2$ & 0.2 & & \\
\hline
\end{tabular}

\section{Results}

\section{Energy yield potential from harvestable crop residues}

The total production of different food crops with harvestable residue (cereals, oil crops, pulses, sugar crops, root crops) varied in the studied period 1997-2006 from 4.8 to 5.1 billion tonnes (Table 2). The biggest group was cereals, the production of which was about 2.1 billion tonnes year ${ }^{-1}$. The cur- rent technically harvestable residue energy potential of these crop groups is about 39-42 EJ at present, and 38-41 EJ in 2050 (Table 2). In practice, even the technical potential overestimates the real attainable crop residue yield as some of the crop residue, in addition to the stubble, has to be ploughed in or left on the ground for better organic matter content and functionality of the soil. The amount needed for satisfactory soil functioning varies according to area and yield of the crop (Graham et al. 2007), and is not defined reliably enough for all the studied areas to be taken into account in this study. 
Hakala, K. et al. Field biomass as global energy source

\section{Food usage and availability of field area for bioenergy crop production}

The results show that enough food is produced at present in the world to satisfy the diet of every inhabitant, even without taking into account permanent grassland productivity (Table $4 \mathrm{a}$ ). The total global GE production, as calculated here, is at present (average of 1997-2006) 5.5 billion tonnes year $^{-1}$ and the GE value per person is 824 , which is approximately sufficient for a moderate $\operatorname{diet}(\mathrm{GE}$ requirement 860, Penning de Vries et al.1997). In 2050 , if only climate change effects and increase in world population (United Nations 2007) are taken into account, the total global GE production would be 5.3 billion tonnes year ${ }^{-1}$ and the GE per capita would be 575, which still would be sufficient for vegetarian diet for each inhabitant (GE requirement 490, Penning de Vries et al.1997) (Table 4b). If also technological development would be added to the calculations, the sufficiency of food would increase considerably. E.g. if only western Europe, eastern Europe and the former Soviet Union countries would reach yield levels possible for those regions, the GE value of world would be 6.8 billion tonnes by 2050 , and would suffice for a mixed vegetarian-meat diet (GE 744 per capita) for everyone living in the world (results not shown).

Food production is, however, not evenly distributed. For example, South Korea (SKO) and Japan (JPN) are not self sufficient in food, but they are solvent enough to be able to import foodstuffs. The situation is more difficult in Africa (AFR), which is clearly deficient in food production, and will be more so in 2050 (Table 4). If considered only on the basis of the studied 15 districts, with no food trade assumed, fields could be set aside from food production for bioenergy crops both now and in the future in AUS, CAN, CSA, EEU, FSU, MEX and USA if a vegetarian diet were adopted (Table 4). With affluent diet, only AUS and CAN could still be producing bioenergy crops on fields. If an exercise is taken to look at technological development as above for Europe, filling the yield gap and positive effects of climate change in WEU would result in possibility of bioenergy production in this area as well (results not shown). If, however, food would be divided equally and food availability would be secured for everyone in a better world, no field area would be freed for bioenergy production, provided food is produced with the present technology and present crops.

For the calculation of potentially produced biomass energy on set-aside fields, the energy values of the energy crops and their yields were calculated per hectare (Table 3 ). The global gross yield of biomass energy from specifically cultivated energy crops would be (with vegetarian diet) 83-91 EJ now and 64-70 EJ in the future (Table 4). The biggest producers of field energy crops for both the present and for 2050 would be AUS, CSA and USA. Positive technological development, e.g. irrigation in areas where water resources could be taken into use, might change the figures for the future dramatically. E.g., if the production technology in Europe alone would proceed according to the scenarios of Ewert et al. (2005) and Olesen and Bindi (2002), the global biomass energy potential would increase to $132 \mathrm{EJ}$ (results not shown).

The total field biomass energy potential is the sum of crop residue technical potential and bioenergy crop energy potential (Table 5). When this sum is used, all areas in the world are assigned a value. The biggest field energy producers would understandably be those that could produce most energy crop biomass (AUS, CSA and USA). The total energy yield from field biomass would be (if vegetarian diet would be assumed) 122-133 EJ now (1997-2006) and 101-110 EJ in 2050 (Table $5)$.

\section{Discussion}

\section{Sustainability of residue collection for bioenergy}

Agricultural residues are one of the most reliable bioenergy sources for the future because they are always produced when crops are grown. In this study, 
Vol. 18 (2009): 347-365.

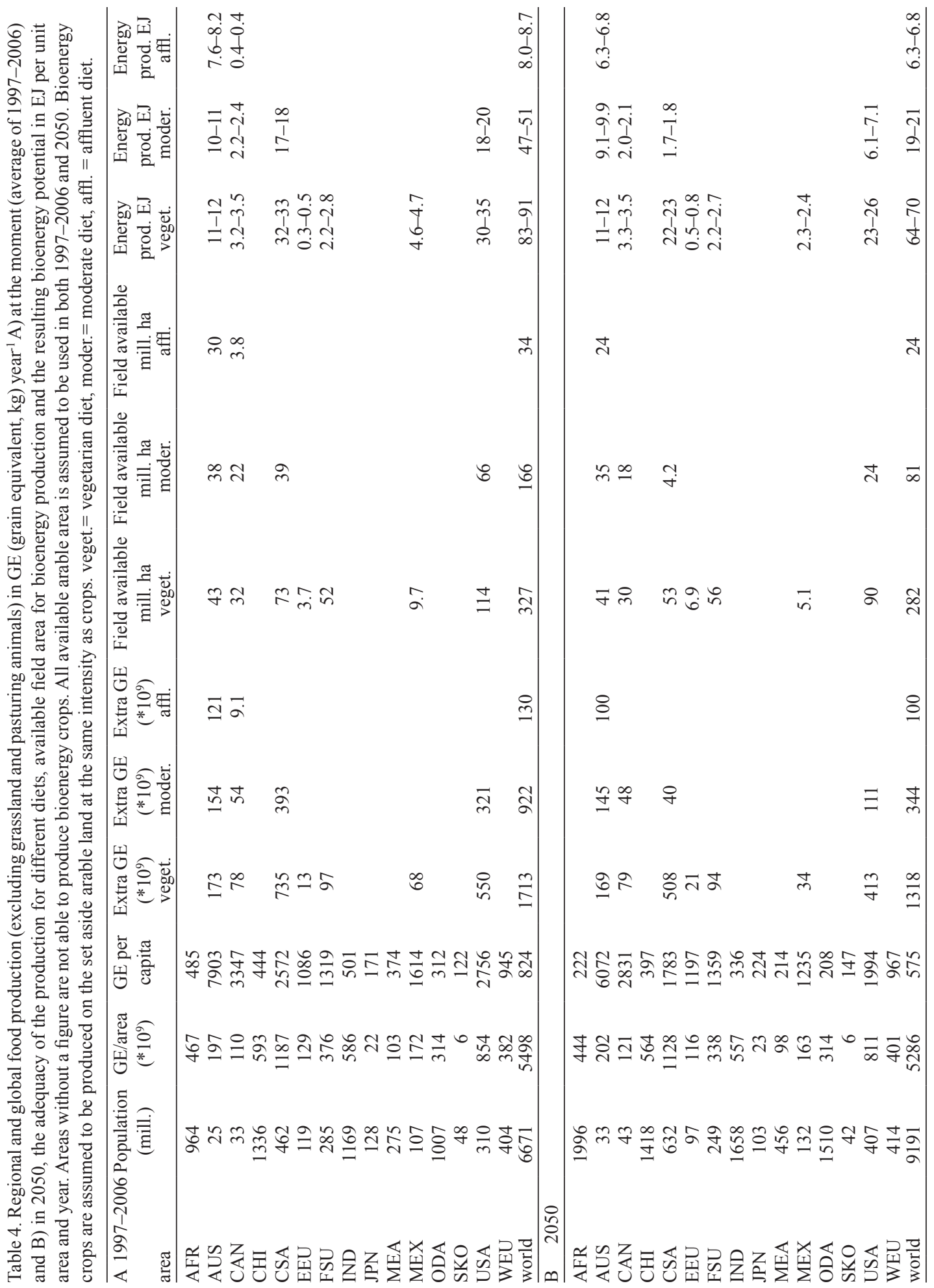


Hakala, K. et al. Field biomass as global energy source

Table 5. Total potential field bioenergy yield $\left(\mathrm{EJ} \mathrm{year}^{-1}\right)$ from primary agricultural residues and bioenergy crops for different diets now (variation in 1997-2006) and in 2050 (variation according to that at present). Permanent grassland production is not included in calculations. veget. = vegetarian diet, moder. = moderate diet, affl. $=$ affluent diet.

\begin{tabular}{|c|c|c|c|c|}
\hline \multirow[b]{2}{*}{ 1997-2006 } & \multirow[t]{2}{*}{ Residues EJ } & \multicolumn{3}{|c|}{ Residues+Bioenergy crops EJ } \\
\hline & & veget. & moder. & affl. \\
\hline AFR & $2.4-2.6$ & $2.4-2.6$ & $2.4-2.6$ & $2.4-2.6$ \\
\hline AUS & $0.6-0.7$ & $11-13$ & $10-11$ & $8.2-8.9$ \\
\hline CAN & $0.8-0.9$ & $4.1-4.4$ & $3.0-3.3$ & $1.2-1.3$ \\
\hline $\mathrm{CHI}$ & $6.5-6.9$ & $6.5-6.9$ & $6.5-6.9$ & $6.5-6.9$ \\
\hline CSA & $4.9-5.4$ & $37-38$ & $22-23$ & $4.9-5.4$ \\
\hline EEU & $1.1-1.3$ & $1.4-1.7$ & $1.1-1.3$ & $1.1-1.3$ \\
\hline FSU & $2.1-2.4$ & $4.4-5.2$ & $2.1-2.4$ & $2.1-2.4$ \\
\hline IND & $5.0-5.3$ & $5.0-5.3$ & $5.0-5.3$ & $5.0-5.3$ \\
\hline JPN & $0.1-0.1$ & $0.1-0.1$ & $0.1-0.1$ & $0.1-0.1$ \\
\hline MEA & $0.9-1.0$ & $0.9-1.0$ & $0.9-1.0$ & $0.9-1.0$ \\
\hline MEX & $0.6-0.6$ & $5.2-5.3$ & $0.6-0.6$ & $0.6-0.6$ \\
\hline ODA & $5.4-5.8$ & $5.4-5.8$ & $5.4-5.8$ & $5.4-5.8$ \\
\hline $\mathrm{SKO}$ & $0.1-0.1$ & $0.1-0.1$ & $0.1-0.1$ & $0.1-0.1$ \\
\hline USA & $5.4-5.7$ & $36-41$ & $23-26$ & $5.4-5.7$ \\
\hline WEU & $3.0-3.1$ & $3.0-3.1$ & $3.0-3.1$ & $3.0-3.1$ \\
\hline world & $39-42$ & $122-133$ & 86-93 & $47-50$ \\
\hline 2050 & & veget. & moder. & affl. \\
\hline AFR & $2.3-2.4$ & $2.3-2.4$ & $2.3-2.4$ & $2.3-2.4$ \\
\hline AUS & $0.6-0.7$ & $11-12$ & $10-11$ & $6.9-7.6$ \\
\hline CAN & $0.9-1.0$ & $4.2-4.5$ & $2.9-3.1$ & $0.9-1.0$ \\
\hline $\mathrm{CHI}$ & $6.2-6.5$ & $6.2-6.5$ & $6.2-6.5$ & $6.2-6.5$ \\
\hline CSA & $4.7-5.1$ & $27-28$ & $6.4-6.9$ & $4.7-5.1$ \\
\hline EEU & $1.0-1.1$ & $1.6-1.9$ & $1.0-1.1$ & $1.0-1.1$ \\
\hline FSU & $1.9-2.1$ & $4.1-4.9$ & $1.9-2.1$ & $1.9-2.1$ \\
\hline IND & $4.8-5.1$ & $4.8-5.1$ & $4.8-5.1$ & $4.8-5.1$ \\
\hline JPN & $0.1-0.1$ & $0.1-0.1$ & $0.1-0.1$ & $0.1-0.1$ \\
\hline MEA & $0.9-1.0$ & $0.9-1.0$ & $0.9-1.0$ & $0.9-1.0$ \\
\hline MEX & $0.5-0.6$ & $2.8-2.9$ & $0.5-0.6$ & $0.5-0.6$ \\
\hline ODA & $5.4-5.8$ & $5.4-5.8$ & $5.4-5.8$ & $5.4-5.8$ \\
\hline SKO & $0.1-0.1$ & $0.1-0.1$ & $0.1-0.1$ & $0.1-0.1$ \\
\hline USA & $5.2-5.4$ & $28-32$ & $11-13$ & $5.2-5.4$ \\
\hline WEU & $3.1-3.2$ & $3.1-3.2$ & $3.1-3.2$ & $3.1-3.2$ \\
\hline world & $38-41$ & $101-110$ & $57-61$ & 44-47 \\
\hline
\end{tabular}

the estimated global technically harvestable crop residue energy potential was about $40 \mathrm{EJ}$ at present and in the future. The figure corresponds well with that from previous studies (Lal 2005). However, the use of crop residues for energy depends on many factors other than technical harvesting potential.
One of these is conservation of soil structure and its organic matter content.

Crop residues left in the field improve the quality of soils. Crop residues on the field surface protect it from water and wind erosion. Residues improve soil structure and water filtration into the soil, and reduce evaporation, thereby improving 
Vol. 18 (2009): 347-365.

crops' capacity to withstand dry periods better. Organic matter in crop residues also increases soil organic matter (SOM) content (Andrews 2006, Blanco-Canqui and Lal 2008), with further benefits for soil functioning. SOM is an important factor in soil fertility and it affects both physical and chemical properties of the soil (Bot and Benites 2005, Griffin 2008). Typically SOM is $2 \%-10 \%$. If crop residue removal results in increased soil erosion and higher runoff rates this would greatly decrease SOM and nutrient content (Andrews 2006).

Accurate instructions for crop residue management, based on experimental research, are not yet available. Most information is available in the US corn production area and for harvest of corn stover as bioenergy (Wilhelm et al. 2007, Varvel and Wilhelm 2008). According to these studies a safe amount of stover harvest depends on soil properties (sensitivity to erosion), climatic conditions and biomass yield of the corn crop. If the yield of corn is low and no-till is not used, then all crop residues must be left in the field (Wilhelm et al. 2007). If no-till cultivation (growing crops without tillage) is used, $30 \%$ of crop residues can be harvested without danger of increased soil erosion (Lindstrom 1986, Andrews 2006). On average, only about $30 \%$ of the corn crop residues can be sustainably collected in the USA for bioenergy or other uses without endangering soil fertility (Graham et al. 2007). In northern production areas, and if yields are high, up to $60 \%$ of corn stover can be safely harvested (Graham et al. 2007). In a Canadian study, $40 \%$ of wheat residue could be harvested in 2 years out of three without affecting soil productivity (Lafond et al. 2009). In cool climates, such as Finland, where the growing season is short and crop residues on the soil surface can reduce crop yields by slowing soil warming, their removal at least partly could even enhance yield formation.

In this study the technical biomass potential (harvestable biomass) was estimated by subtracting the portion of the crop left in the field at harvest (stubble and shed straw) from theoretical biomass potential. The calculation of sustainable biomass potential would require valid estimates of the amount of crop residue needed to retain soil fertility. As there is limited information concern- ing the amounts of crop residue needed to sustain soil fertility, numerical estimates of the sustainable biomass potential are not given in this report. Areas where crop residue removal is likely to impair soil fertility and cause erosion are those where water shortage currently limits crop production, and where the limitation will become more severe with climate change. These areas are IND, MEX, USA, AFR, AUS, MEA, CHI, and some countries in ODA (IPCC 2007b, Parry et al. 2004). In the northern hemisphere, where the climate is more humid, the extensive and sustainable use of crop residues for bioenergy is still possible.

\section{Food and bioenergy - prospects with and without fair share}

Global food production is sufficient for every individual now and will be in the future if development occurs in a sustainable manner as suggested by emission scenario B1 (Nakicenovic et al. 2000, Olesen and Bindi 2002, Parry et al. 2004, IPCC 2007a, IPCC 2007b). According to our results, however, the studied areas differ greatly in their self sufficiency. AFR has and will have difficulty producing adequate amount of food, especially given that its population will double from the current one billion to about two billion in 2050 (United Nations 2007). In some previous reports of food production sufficiency and possible bioenergy production, different African regions were reported to be well able to feed themselves (Penning de Vries et al. 1997), and even to produce bioenergy crops (Berndes et al. 2003, Hoogwijk et al. 2005). Many of the studies concerning biomass production estimates are, however, based on potential global production, not what is actually harvested. When seen in this way, the potential biomass production ranges from $<100$ EJ to $>400$ EJ (Berndes et al. 2003, Hoogwijk et al. 2005), even reaching 648 EJ when all land suitable for biomass production is used efficiently (Wolf et al. 2003). Our study is based on production values derived from actual global statistics, not production potential per se. Thus, the influence of political instability, underdeveloped infrastructure 


\section{Hakala, K. et al. Field biomass as global energy source}

and low technological development on a regional basis is taken into account in the actual production data (Table 2) and the resulting food sufficiency (Table 4). If permanent grassland production could be estimated, our study would probably have indicated higher GE and bioenergy production values. However, the present results seem realistic, at least for AFR, as the threat of increasing undernourished population in the area has been reported by the IPCC (IPCC 2007b). Fulfilling the need for food, and being able to produce bioenergy crops seems very unlikely for AFR without substantial technological progress occurring in the future.

In order to efficiently produce energy from field biomasses, the choice of the energy crop is crucial. E.g. maize and sugar cane are very efficient biomass and energy producers given the right conditions, whereas huge potential lies in the vast areas of permanent grasslands that form $70 \%$ of all agricultural area and are at the moment not efficiently used. For full exploitation of maize for bioenergy, taking into account that it also is used as food, its yield as well as the conversion of the yield and biomass to bioethanol has to be improved (Torney et al. 2007). The same demands apply to permanent grasslands, where improvement of productivity largely depends on adequacy of nutrients, water and transport logistics.

Sugar cane production for energy in suitable climates and areas could increase the energy yield from agricultural areas considerably. E.g. in Brazil, the total agricultural area is 264 million hectares, of which permanent pastures comprise almost 200 million hectares (FAO 2009). The increase in sugar cane production area from 4.8 to 6.4 million hectares in 1997-2006 (FAO 2009) has according to Brazilian experts mainly taken place at the expense of the permanent pasture areas and small farms of varied crops with almost no impact on arable land (Goldemberg et al. 2008). Sugar cane production could still be increased on pasturelands, as the number of cattle $\mathrm{km}^{-2}$ is still very low and could be increased (Goldemberg et al. 2008). However, further increase in sugar cane production area in the coming decades may require deforestation and expansion to savannah (cerrado), which is an important natural habitat in Brazil. Luckily these kind of natural habitats are largely not suitable for intensive farming, because of soil quality, low precipitation and logistics, and also local laws tend to protect natural habitats (Goldemberg et al. 2008).

Usage of sugar cane and maize for bioenergy, while there still are areas in the world where population is undernourished has raised debate in public. Therefore, locally adapted natural plants such as Jathropa or castor bean could be taken into cultivation on large areas, provided their toxicity is reduced by breeding or genetic modification first (Gressel 2008). Genetic modification would also be required to improve cellulose biosynthesis and modify lignin content in lignocellulosic crops and straw to reduce the costs of lignin removal in this kind of biomass crops (Gressel 2008).

In this study we were not able to take into account international trade in foodstuffs. Thus, when JPN and SKO buy food, the GE overproduction will diminish in the areas providing that food. For example, Australia is a major wheat exporter and will most probably not start to produce bulk bioenergy crops on additional field area if it can export food profitably. Therefore, the bioenergy potential reported here has to be considered carefully. There is also danger of reduction in agricultural area. In Europe the arable land area is currently (average of years 2000-2005) 15\% and the agricultural area, $30 \%$ lower than for the long-term average of 1977 to 1999 (FAO 2009). Some of this loss is attributable to urbanisation, but some results from yield improvement, technology development and reduced need for food production. Problems with land degradation can also occur. E.g. in Australia the agricultural area is decreasing because of drought and salinisation, but so far Australia has been able to keep the arable area constant (FAO 2009), probably with higher investments in technology.

\section{Conclusions}

According to our results total food production in the world should be just sufficient to provide a healthy diet for the entire population, both now and in the 


\section{AGRICULTURAL AND FOOD SCIENCE}

Vol. 18 (2009): 347-365.

future, even considering only arable farming (not permanent grassland). If food were distributed evenly, however, no field area would be available for bioenergy crop production. Improvement of crop production technology and breeding for higher yields and better quality would increase the area freed from food production and improve the efficiency of energy production in these set aside fields substantially. Crop residues will always be a potential biomass energy source, but the extent of their sustainable use requires more information and studies that take local climate conditions into account.

Acknowledgements. Financial support was provided by the Climbus Program of Tekes, the Finnish Funding Agency for Technology and Innovation, MTT Agrifood Research Finland, the Technical Research Centre of Finland (VTT) and Fortum, all of whom are gratefully acknowledged.

\section{References}

Andrews, S.S. 2006. Crop residue removal for biomass energy production: Effects on soils and recommendations. Updated 22 February 2006. Cited on 10 September 2009.15 p. Available on the internet: http://soils. usda.gov/sqi/management/files/agforum_residue_ white_paper.pdf.

Berndes, G., Hoogwijk, M. \& van den Broek, R. 2003. The contribution of biomass in the future global energy supply: a review of 17 studies. Biomass and Bioenergy 25: 1-28.

Blanco-Canqui, H. \& Lal, R. 2008. Corn stover removal impacts on micro-scale soil physical properties. Geoderma 145: 335-346.

Bot, A. \& Benites, J. 2005. The importance of soil organic matter: Key to drought resistant soil and sustained food and production. FAO Soils Bulletin 80. Food and Agriculture Organization of the United Nations, Rome, 2005. Cited on 15 June 2009. Available on the internet: ftp:// ftp.fao.org/agl/agll/docs/sb80e.pdf.

EEA (European Environment Agency) 2008. Greenhouse gas emission trends and projections in Europe 2008. EEA Report 5/2008.

Ewert, F., Rounsevell, M.D.A., Reginster, I., Metzger, M.J. \& Leemans, R. 2005. Future scenarios of European agricultural land use I. Estimating changes in crop productivity. Agriculture, Ecosystems \& Environment 107: 101-116.

FAO 2009. Homepage of Food and Agriculture Organization of the United Nations. Cited on 15 June 2009. Available on the internet: http://faostat.fao.org.
Goldemberg, J., Coelho, S.T. \& Guardabassi, P. 2008. The sustainability of ethanol production from sugarcane. Energy Policy 36: 2086-2097.

Graham, R.L., Nelson, R., Sheehan, J., Perlack, R.D. \& Wright, L.L. 2007. Current and potential U.S. corn stover supplies. Agronomy Journal 99: 1-11.

Gressel, J. 2008. Transgenics are imperative for biofuel crops. Plant Science 174: 246-263.

Griffin, T. 2008. Soil Organic Matter. University of Maine Cooperative Extension, Bulletin 2288. Cited on 2 September 2009. Available on the internet: http://www. umext.maine.edu/onlinepubs/htmpubs/2288.htm.

Hoogwijk, M., Faaij, A., Eickhout, B., de Vries, B. \& Turkenburg, W. 2005. Potential of biomass energy out to 2100 , for four IPCC SRES land-use scenarios. Biomass and Bioenergy 29: 225-257.

IPCC 2007a. Summary for Policymakers. In: Climate Change 2007: The Physical Science Basis. Contribution of Working Group I to the Fourth Assessment Report of the Intergovernmental Panel on Climate Change. Solomon, S., D. Qin, M. Manning, Z. Chen, M. Marquis, K.B. Averyt, M. Tignor \& H.L. Miller (eds). Cambridge University Press, Cambridge, United Kingdom and New York, NY, USA. 18 p.

IPCC 2007b. Summary for Policymakers. In: Climate Change 2007: Impacts, Adaptation and Vulnerability. Contribution of Working Group II to the Fourth Assessment Report of the Intergovernmental Panel on Climate Change. Parry, M.L., Canziani, O.F., Palutikof, J.P., van der Linden P.J. \& Hanson, C.E. (eds) Cambridge University Press, Cambridge, UK. $16 \mathrm{p}$.

Koljonen, T., Flyktman, M., Lehtilä, A., Pahkala, K., Peltola, E. \& Savolainen, I. 2009. The role of CCS and renewables in tackling climate change. Energy Procedia 1: 4323-4330. Greenhouse Gas Control Technologies 9, Proceedings of the 9th International Conference on Greenhouse Gas Control Technologies (GHGT-9), 1620 November 2008, Washington DC, USA.

Lafond, G.P., Stumborg, M., Lemke, R., May, W.E., Holzapfel, C.B. \& Campbell, C.A. 2009. Quantifying straw removal through baling and measuring the long-term impact on soil quality and wheat production. Agronomy Journal 101: 529-537

Lal, R. 2005. World crop residues production and implications of its use as a biofuel. Environment International 31: 575-584.

Lindstrom, M.J. 1986. Effects of residue harvesting on water runoff, soil-erosion and nutrient loss. Agriculture Ecosystems \& Environment 16: 103-112.

Nakicenovic N., Alcamo J., Davis G., de Vries B., Fenhann J., Gaffin S., Gregory K., Grübler A., Jung T.Y., Kram T., La Rovere E.L., Michaelis L., Mori S., Morita T., Pepper W., Pitcher H., Price L., Raihi K., Roehrl A., Rogner H.-H., Sankovski A., Schlesinger M., Shukla P., Smith S., Swart R., van Rooijen S., Victor N. \& Dadi Z., 2000. Emissions Scenarios. A Special Report of Working Group III of the Intergovernmental Panel on Climate Change. Cambridge University Press, 599 p.

Olesen, J.E. \& Bindi, M. 2002. Consequences of climate change for European agricultural productivity, land use and policy. European Journal of Agronomy 16: 239262.

Pahkala, K., Aalto, M., Isolahti, M., Poikola, J. \& Jauhiain- 


\title{
AGRICULTURAL AND FOOD SCIENCE
}

\author{
Hakala, K. et al. Field biomass as global energy source
}

en, L. 2008. Large-scale energy grass farming for power plants-A case study from Ostrobothnia, Finland. Biomass and Bioenergy 32: 1009-1015.

Pahkala, K., Hakala, K., Kontturi, M. \& Niemeläinen, O. 2009. Peltobiomassat globaalina energianlähteenä. Maa- ja elintarviketalous 137. 53 p. Cited on 15 June 2009. Available on the internet: http://www.mtt.fi/met/ pdf/met137.pdf. (In Finnish.)

Pahkala, K., Kontturi, M., Kallioinen, A., Myllymäki, O., Uusitalo, J., Siika-Aho, M. \& Weymarn, N. von 2007. Production of bio-ethanol from barley straw and reed canary grass: a raw material study. In: Proceedings of the 15th European Biomass Conference \& Exhibition in May in Berlin, Germany. Berlin: ETA-Renewable Energies. p. 154-157.

Pahkala, K. \& Kontturi, M. 2008. Korsibiomassojen laatu bioetanolin raaka-aineena. In: Hopponen, A. (ed.) Maataloustieteen Päivät 2008, 10.-11.1.2008. Suomen maataloustieteellisen seuran tiedote 23: $6 \mathrm{p}$. Cited on 15 June 2009. Available on the internet: http://www. smts.fi/mpol2008/index_tiedostot/Esitelmat/es044. pdf. (In Finnish.)

Parry, M.L., Rosenzweig, C., Iglesias, A., Livermore, M. \& Fischer, G. 2004. Effects of climate change on global food production under SRES emissions and socioeconomic scenarios. Global Environmental Change 14: $53-67$.

Penning de Vries, F.W.T, Rabbinge, R. \& Groot, J.J.R. 1997. Potential and attainable food production and food security in different regions. Philosophical Transactions of the Royal Society B Biological Sciences 352: 917-928.

REN21 2008. Renewables 2007 Global Status Report. Paris: REN21 Secretariat and Washington, DC: Worldwatch Institute. Cited on 15 June 2009. Available on the internet: http://www.ren21.net/.

Schmer, M.R., Vogel, K.P., Mitchell, R.B. \& Perrin, R.K. 2008. Net energy of cellulosic ethanol from switchgrass. PNAS 105: 464-469. Cited on 24 November 2008. Available on the internet: www.pnas.org/cgi/doi/10.1073/ pnas. 0704767105.

Sims, R.E.H. Schock, R.N.. Adegbululgbe, A., Fenhann, J., Konstantinaviciute, I., Moomaw, WW., Nimir, H.B., Schlamadinger, B., Torres-Martínez, J., Turner, C., Uchiyama, Y., Vuori, S.J.V., Wamukonya, N. \& Zhang, X. 2007. Energy supply. In: Climate Change 2007 - Mitigation. Contribution of Working Group III to the Fourth Assessment Report of the Intergovernmental Panel on Climate Change [B. Metz, O.R. Davidson, P.R. Bosch, R. Dave \& L.A. Meyer (eds)], Cambridge University Press, Cambridge, United Kingdom and New York, NY, USA.

Staniforth, A.R. 1979. Cereal straw. Oxford University Press, Oxford, UK. 175 p.
Syri, S., Koljonen, T., Abdurafikov, R., Ekholm,T., Flyktman, M., Forsstöm, J., Helynen, S., Holttinen, H., Kekkonen, V., Koreneff, G., Lehtilä, A., Lemström, B., Peltola, E., Korhonen, I., Ollus, S.-E., Solanko, L., Pahkala, K., Hakala, K., Kontturi, M. \& Niemeläinen, O. 2008a. Suomalaisen energiateollisuuden kilpailukyky ilmastopolitiikan muuttuessa-SEKKI. (The competitiveness of Finnish energy industry under developing climate policy) In: Jussila, J. (ed.) Ilmaston muutoksen hillinnän liiketoimintamahdollisuudet. Tekesin katsaus 235/2008: 65-72. (In Finnish, with English Abstract.)

Syri, S., Lehtilä, A., Ekholm, T., Savolainen, I., Holttinen, H. \& Peltola, E. 2008b. Global energy and emissions scenarios for effective climate change mitigation - Deterministic and stochastic scenarios with the TIAM model. International Journal of Greenhouse Gas Control 2: 274-285.

Torney, F., Moeller, L., Scarpa, A., \& Wang, K. 2007. Genetic engineering approaches to improve bioethanol production from maize. Current Opinion in Biotechnology 18: 193-199.

United Nations 1998. Kyoto protocol to the United Nations framework convention on climate change. Cited on 3 September 2009. Available on the internet: http://unfccc.int/resource/docs/convkp/kpeng.pdf.

United Nations 2007. World Population Prospects: The 2006 Revision. Cited on 10 September 2009. Available on the internet: http://www.un.org/esa/population/publications/wpp2006/WPP2006_Highlights_rev.pdf.

UNFCCC (United Nations framework convention on climate change). Kyoto protocol reference manual on accounting of emissions and assigned amount. Cited on 2 September 2009. Available on the internet: http://unfccc.int/resource/docs/publications/08_unfccc_kp_ref_ manual.pdf.

Varvel, G.E. \&Wilhelm, W.W. 2008. Soil carbon levels in irrigated western Corn Belt rotations. Agronomy Journal 100: 1180-1184.

Wilhelm W.W., Johnson J.M.E., Karlen D.L. \& Lightle D.T. 2007. Corn stover to sustain soil organic carbon further constrains biomass supply. Agronomy Journal 99: 1665-1667.

Wolf, J., Bindraban, P.S., Luijten, J.C. \& Vleeshouwers, L.M. 2003. Exploratory study on the land area required for global food supply and the potential global production of bioenergy. Agricultural Systems 76: 841-861.

Woods, J., Tipper, R., Brown, G., Diaz-Chavez, R., Lovell, J. \& de Groot, P. 2006. Evaluating the sustainability of co-firing in the UK. Themba Technology Ltd and the Edinburgh Centre for Carbon Management. DTI Report URN 06/1960. 63 p. Cited on 11 November 2008. Available on the internet: http://www.berr.gov.uk/files/ file34448.pdf. 
Vol. 18 (2009): 347-365.

\title{
SELOSTUS
}

\section{Peltobiomassa globaalina energianlähteenä}

\author{
Kaija Hakala, Markku Kontturi ja Katri Pahkala \\ MTT (Maa- ja elintarviketalouden tutkimuskeskus)
}

Peltobiomassan nykyistä (1997-2006) ja tulevaa (2050) globaalia energiapotentiaalia arvioitiin FAO:n tuotantotilastojen avulla. Tulevaa potentiaalia arvioitiin Hallitusten välisen ilmastonmuutospaneelin (IPCC) päästöskenaarion B1 pohjalta. Tässä päästöskenaariossa maapallon kasvihuonekaasupäästöjen ja väestön kasvun ennustetaan vähitellen laskevan. Tähän kehitykseen vaikuttavat uusiutuvien energialähteiden käyttö ja yhteistyö valtioiden välillä. Tutkimuksessa arvioitiin erikseen peltokasvituotannon sivutuotteista (olki, naatit jne.) saatava energiapotentiaali sekä ruoantuotannosta poistuvan ja bioenergiakasvien tuotantoon siirtyvän peltoalan biomassan tuotosta saatava energiapotentiaali. Yhteensä peltobiomassaan sisältyvä energiapotentiaali olisi tällä hetkellä $122-133$ EJ $\left(\mathrm{EJ}=\mathrm{J} \times 10^{18}\right), 86-93$ EJ tai $47-50$ EJ vuodessa, jos väestön ruokavalio olisi (vastaavassa järjestyksessä) kasvis-, seka- tai lihapainotteinen ruokavalio. Määrät ovat merkittäviä, sillä esimerkiksi Suomen koko energiankulutus vuodessa on 1,5 EJ ja maailman koko energiankulutus 464 EJ. Vuonna 2050 vastaavat peltobiomassasta saatavat teoreettiset energia-arvot olisivat 101-110 EJ, 57-61 EJ ja 44-47 EJ vuodessa ruokavaliosta riippuen (kasvis-, seka- ja lihapainotteinen ruokavalio). Vuoden 2050 arviot ovat pienempiä kuin nykyisen potentiaalin arviot, koska ilmastonmuutos heikentää suurilla tuotantoalueilla ruoantuotannon edellytyksiä muun muassa lisääntyvän kuivuuden takia. Lisäksi kasvavasta väestömäärästä johtuen yhä suurempi osa peltoalasta tarvitaan ruoantuotantoon. Peltokasvituotannon sivutuotteiden osuus pellolta saatavasta bioenergiasta voisi tällä hetkellä olla 39-42 EJ ja vuonna 2050
38-41 EJ vuodessa. Kuitenkin jo tällä hetkellä maan kasvukunnon ja kestävän viljelyn kannalta sopiva poiskorjattavien kasvintähteiden määrä riippuu ilmasto- ja viljelyoloista. Tulevaisuudessa ilmaston lämpeneminen kiihdyttää maaperän mikrobiologisia prosesseja ja siten yhä suurempi osuus korjuutähteistä on jätettävä pellolle, jotta maaperän eloperäisen aineksen määrä säilyisi riittävänä. Tämän vuoksi nyt esitetyt korjuutähteiden käyttöluvut ovat vain teoreettisia ja niiden todellinen käyttömahdollisuus bioenergiaksi on näitä lukuja pienempi. Varsinaisten bioenergiakasvien viljelyä olisi näillä näkymin mahdollista lisätä Australiassa, Etelä- ja Keski-Amerikassa sekä USA:ssa. Jos viljelymenetelmiä pystytään tehostamaan ruoantuotannossa, ilmastolliset tekijät mahdollistaisivat bioenergiantuotannon lisäämisen myös entisen Neuvostoliiton valtioissa sekä suuressa osassa Eurooppaa. Peltobioenergian tuotanto on tämän tutkimuksen mukaan todellinen vaihtoehto fossiilisille polttoaineille. Tuotannon tehokkuus, kestävyys ja eettisyys riippuvat kuitenkin kasvintuotannon teknisestä kehityksestä, olojen vakaudesta ja siitä, saadaanko ruoka jaettua tasan maailman eri alueiden kesken. Jos maailman koko ruoantuotanto jaettaisiin tasan, ruokaa riittäisi sekä nyt että tulevaisuudessa kaikille - väestön kasvusta huolimatta, ja bioenergiaksikin riittäisi peltobiomassaa, vaikka peltoalaa ei tällöin voitaisikaan valjastaa bioenergiakasvien tuotantoon. Jos tällaista tasajakoa ei toteuteta, suuri osa maailman maista voisi jo nyt, ja myös tulevaisuudessa, korvata merkittävän osan energiantarpeestaan peltobiomassasta saatavalla uusiutuvalla energialla. 
Hakala, K. et al. Field biomass as global energy source

\section{Appendix}

APPENDIX 1. The studied areas, their coefficients for crop production for 2050 (in parentheses) and the countries they comprise. The division is based on the Global Times modelling approach used in the Finnish SEKKI project.

AFR (0.95): Algeria, Angola, Benin, Botswana, Burkina Faso, Burundi, Cameroon, Cape Verde, Central African Republic, Chad, Comoros, Congo, Congo, Democratic Republic of, Côte d'Ivoire, Djibouti, Egypt, Equatorial Guinea, Eritrea, Ethiopia, Gabon, Gambia, Ghana, Guinea, Guinea-Bissau, Kenya, Lesotho, Liberia, Libyan Arab Jamahiriya, Madagascar, Malawi, Mali, Mauritania, Mauritius, Morocco, Mozambique, Namibia, Niger, Nigeria, Réunion, Rwanda, Sao Tome and Principe, Senegal, Seychelles, Sierra Leone, Somalia, South Africa, Sudan, Swaziland, Tanzania, United Republic of, Togo, Tunisia, Uganda, Zambia, Zimbabwe

AUS (1.025): Australia and New Zealand

CAN (1.1): Canada

CHI (0.95): China

CSA (0.95): Antigua and Barbuda, Argentina, Bahamas, Barbados, Belize, Bermuda, Bolivia, Brazil, British Virgin Islands, Cayman Islands, Chile, Colombia, Costa Rica, Cuba, Dominica, Dominican Republic, Ecuador, El Salvador, French Guiana, Grenada, Guadeloupe, Guatemala, Guyana, Haiti, Honduras, Jamaica, Martinique, Montserrat, Nicaragua, Panama, Paraguay, Peru, Puerto Rico, Saint Kitts and Nevis, Saint Lucia, Saint Vincent and Grenadines, Suriname, Trinidad and Tobago, Uruguay, Venezuela
EEU (0.9): Albania, Bosnia and Herzegovina, Bulgaria, Croatia, Czech Republic, Hungary, Montenegro, Poland, Romania, Serbia, Serbia and Montenegro, Slovakia, Slovenia, The former Yugoslav Republic of Macedonia,

FSU (0.9): Armenia, Azerbaijan, Belarus, Estonia, Georgia, Kazakhstan, Kyrgyzstan, Latvia, Lithuania, Moldova, Russian Federation, Tajikistan, Turkmenistan, Ukraine, Uzbekistan, ,

IND (0.95): India

JPN (1.05): Japan

MEA (0.95): Bahrain, Cyprus, Iran, Islamic Republic of, Iraq, Israel, Jordan, Kuwait, Lebanon, Occupied Palestinian Territory, Oman, Qatar, Saudi Arabia, Syrian Arab Republic, Turkey, United Arab Emirates, Yemen

MEX (0.95): Mexico

ODA (1.0): Afghanistan, American Samoa, Bangladesh, Bhutan, Brunei Darussalam, Cambodia, Cook islands, Fiji, French Polynesia, Guam, Indonesia, Kiribati, Korea, Democratic People's Republic of, Lao People's Democratic Republic, Malaysia, Maldives, Marshall Islands, Micronesia, Mongolia Myanmar, Nauru, Nepal, New Caledonia, Niue, Pakistan, Papua New Guinea, Philippines, Samoa, Singapore, Solomon Islands, Sri Lanka, Thailand, Timor-Leste, Tokelau, Tonga, Tuvalu, Wallis and Futuna Islands, Vanuatu, Viet Nam

SKO (1.05): South Korea

USA (0.95): United States of America

WEU (1.05): Austria, Belgium, Belgium-Luxembourg, Denmark, Faroe Islands, Finland, France, Germany, Greece, Iceland, Ireland, Italy, Luxembourg, Malta, Netherlands, Norway, Portugal, Spain, Sweden, Switzerland, United Kingdom 
Vol. 18 (2009): 347-365.

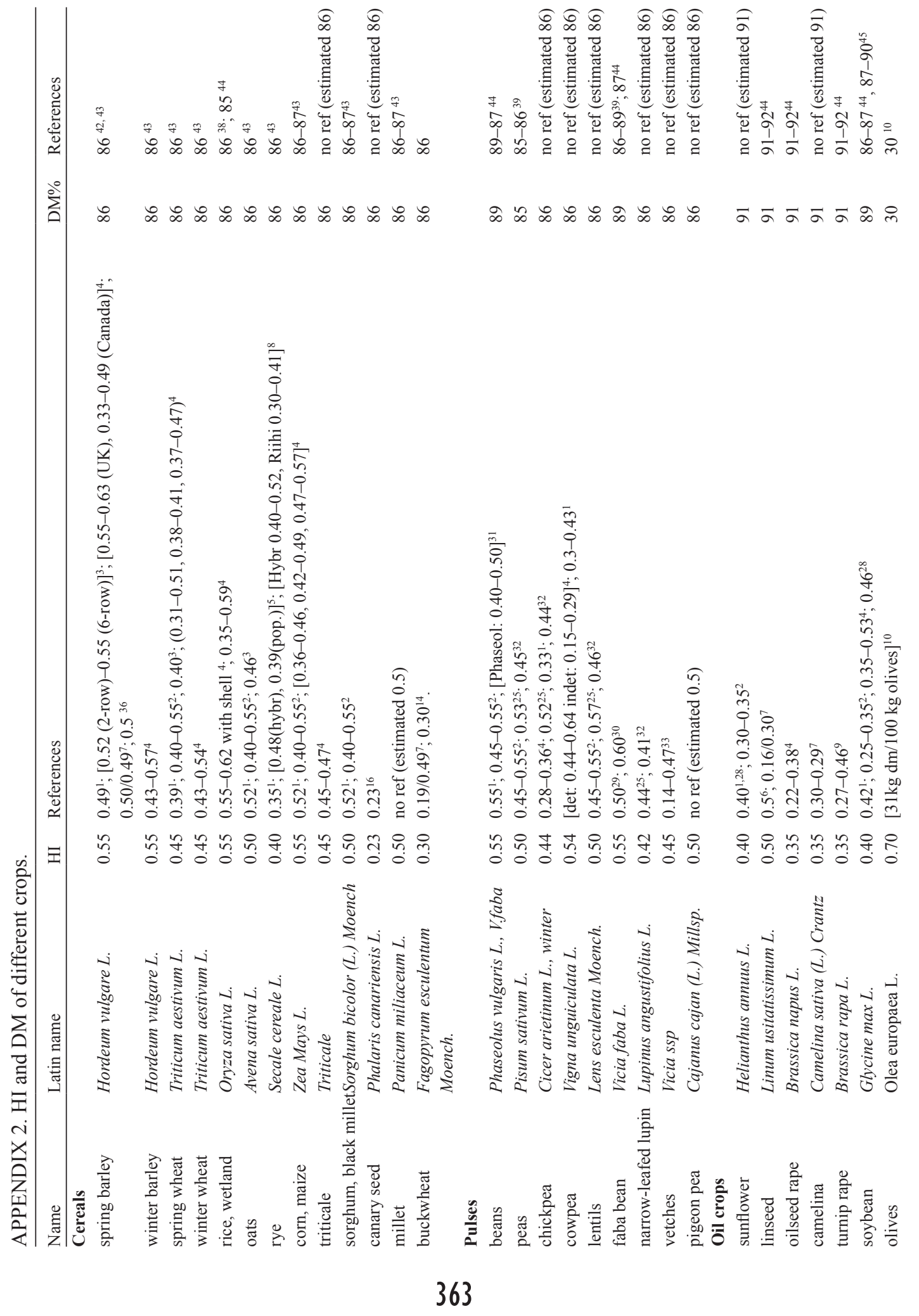


Hakala, K. et al. Field biomass as global energy source

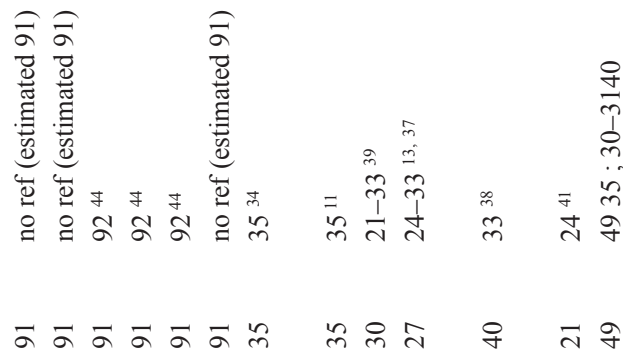

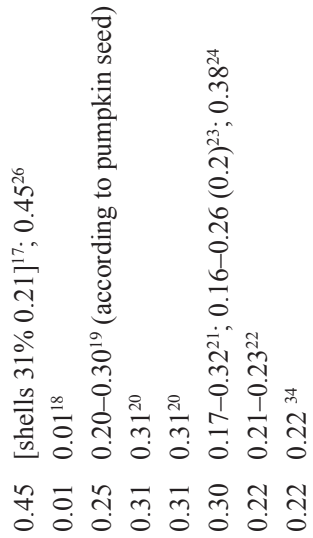

\section{References for APPENDIX 2}

1. Bradford, J.B., Lauenroth, W.K. \& Burke, I.C. 2005. The impact of cropping on primary production in the U. S. Great Plains. Ecology 86:1863-1872. Appendix A in Ecological Archives E086-098-A1. http://www.esapubs.org/Archive/ ecol/E086/098/appendix-A.htm. Cited on 3.9.2009.

2. www.bsyse.wsu.edu/cropsyst/manual/parameters/crop/ harvest.htm. Cited on 5.12.2007 and http://www.bsyse. wsu.edu/cropsyst/. Cited on 3.9.2009.

3. Peltonen-Sainio, P., Muurinen, S., Rajala, A. \& Jauhiainen, L. 2008. Variation in harvest index of modern spring barley, oat and wheat cultivars adapted to northern growing conditions. The Journal of Agricultural Science 146:35-47.

4. Hay, R.K.M. 1995. Harvest index: a review of its use in plant breeding and crop physiology. Annals of Applied Biology 126:197-216.

5. Hakala, K. \& Pahkala, K. 2003. Comparison of central and northern European winter rye cultivars grown at high latitudes. The Journal of Agricultural Science 141: 169-178.

6. Sankari, H. 2000. Linseed (Linum usitatissimum L.) cultivars and breeding lines as stem biomass producers. Journal of Agronomy and Crop Science 184: 225-231.

7. Hakala, K. 2008. MONIKASVI-project, field experiment (2004), pot experiment (2003). Unpublished results.

8. Pahkala, K., Laine, A., Vuorinen, M., Niskanen, M., Hakala, K., Huusela-Veistola, E., Jalli, H., Avikainen, H., Eurola, M. \& Salmenkallio-Marttila, M. 2004. Effect of sowing time and plant protection on tillering, yield, and quality of rye cultivars. In: Simo Hovinen et al. Cultivation of new rye varieties in Finland. Maa- ja elintarviketalous 48: 50-90. http://www.mtt.fi/met/pdf/met48.pdf.

9. Pahkala, K. 2008. Unpublished harvest index results in project Improving yield stability of turnip rape (20022004).

10. TDC Olive. By-product reusing from olive and olive oil production. EU project: FOOD-CT-2004-505524. Technologia Transfer Zentrum, Bremenhaven. http://www.biomatnet.org/publications/1859bp.pdf. Cited on 5.12.2007.

11. Rajan, K.S., Shffiasaki, R. \& Takagi, M. 1995. Simulating agricultural land use changes in Thailand. Proceedings of the 16th Asian Conference on Remote Sensing Nov. 20-24, 1995. Nakhon Ratchasima, Thailand. http:// www.gisdevelopment.net/aars/acrs/1995/ps2/ps2003.asp. Cited on 3.9.2009.

12. Asante, K. \& Dixon, A.G.O. 2006. Field screening of cassava (Manihot esculenta Cranz) germplasm for desirable traits by the use of augmented design. http://www.wajae. org/papers/papers_vol10/field_screening_of_cassava_ full.pdf. Cited on 3.9.2009.

13. Li, H.M 1990. Sweet potato varietal trial. ARC Training. 4 p. http://www.arc-avrdc.org/pdf_files/Lihongmin(8-N). pdf. Cited on 3.9.2009.

14. Schulte auf'm Erley, G., Kaul, H.-P., Kruseb, M. \& Aufhammer, W. 2005. Yield and nitrogen utilization efficiency of the pseudocereals amaranth, quinoa, and buckwheat under differing nitrogen fertilization. European Journal of Agronomy 22: 95-100.

15. Hartemink, A.E., Johnston, M., O'Sullivan, J.N. \& Poloma, S. 2000. Nitrogen use efficiency of taro and sweet potato in the humid lowlands of Papua New Guinea. Agriculture, Ecosystems and Environment 79: 271-280. 


\section{AGRICULTURAL AND FOOD SCIENCE}

Vol. 18 (2009): 347-365.

16. Ford, J.F., Norton R.M., Knights, S.E. \& Flood, R.G. 2001. High sowing rates reduce seed weight in canary seed (Phalaris canariensis L.). The Australian Society of Agronomy. http://www.regional.org.au/au/asa/2001/6/b/ford.htm. Cited on 3.9.2009.

17. Duke, J.A. \& duCellier, J. 1993. CRC Handbook of alternative cash crops. CRC Press, London. p. 49-54.

18. Vanaja, M., Jyothi, M., Ratnakumar, P., Vagheera, P., Reddy, P.R., Lakshmi, N.J., Yadav, S.K., Maheshwari, M. \& Venkateswarlu, B. 2008. Growth and yield responses of Castor bean (Ricinus communis L.) to two enhanced $\mathrm{CO} 2$ levels. Plant Soil Environment 54: 38-46.

19. Loy, J.B. 1990. Hull-less seeded pumpkins: a new edible snackseed crop. In: J.Janick \& J.E Simon (eds). Advances in new crops. Timber Press Portland, OR. p. 403-407. http://www.hort.purdue.edu/newcrop/proceedings1990/ V1-403.html. Cited on 3.9.2009.

20. Venugopalan, M.V. \& Pundarikakshudu, R. 1999. Longterm effect of nutrient management and cropping system on cotton yield and soil fertility in rainfed vertisols. Nutrient Cycling in Agroecosystems 55: 159-164.

21. Koutroubas, S.D., Papakosta, D.K. \& Doitsinis A. 2004. Cultivar and seasonal effects on the contribution of preanthesis assimilates to safflower yield. Field Crops $R e$ search 90: 263-274.

22. El-Habbasha, S.F., Abd El Salam, M.S. \& Kabesh, M.O. 2007. Response of two sesame varieties (Sesamum indicum L.) to partial replacement of chemical fertilizers by bio-organic fertilizers. Research Journal of Agriculture and Biological Sciences 3: 563-571.

23. Yau, S.K. 2007. Winter versus spring sowing of rain-fed safflower in a semi-arid, high-elevation Mediterranean environment. European Journal of Agronomy 26: 249-256.

24. Lovelli, S., Perniola, M., Ferrara, A. \& Di Tommaso, T. 2007. Yield response factor to water (Ky) and water use efficiency of Carthamus tinctorius L. and Solanum melongena L. Agricultural Water Management 92: 73-80.

25. Ayaz, S., McKenzie, B.A., Hill, G.D. \& McNeil, D.L. 2004. Variability in yield of four grain legume species in a subhumid temperate environment I. Yields and harvest index. The Journal of Agricultural Science 142: 9-19.

26. Kiniry, J.R., Simpson, C.E., Schubert, A.M. \& Reed, J.D. 2005. Peanut leaf area index, light interception, radiation use efficiency, and harvest index at three sites in Texas. Field Crops Research 91: 297-306.

27. Lu, H.Y., Lu, C.T., Chan, L.F. \& Wei, M.L. 2001. Seasonal variation in linear increase of taro harvest index explained by growing degree days. Agronomy Journal 93:1136-1141.

28. Johnson, J.M.-F., Allmaras, R.R. \& Reicosky, D.C. 2006. Estimating source carbon from crop residues, roots and rhizodeposits using the national grain-yield database. Agronomy Journal 98: 622-636.

29. Turpin, J.E., Robertson, M,J., Hilcoat, N.S. \& Herridge, D.F. 2002. Faba bean (Vicia faba) in Australia's northern grains belt: canopy development, biomass, and nitrogen accumulation and partitioning. Australian Journal of Agricultural Research 53: 227-237

30. López-Bellido, R.J., López-Bellido, L., López-Bellido, F.J. \& Castillo J.E. 2003. Faba bean (Vicia faba L.) response to tillage and soil residual nitrogen in a continuous rotation with wheat (Triticum aestivum L.) under rainfed Mediterranean conditions. Agronomy Journal 95: 1253-1261.

31. Tesfaye, K., Walker, S. \& Tsubo, M. 2006. Radiation interception and radiation use efficiency of three grain legumes under water deficit conditions in a semi-arid environment. European Journal of Agronomy 25: 60-70

32. Ayaz, S., Moot, D.J., McKenzie, B.A., Hill, G.D. \& McNeil, D.L. 2004. The use of a principal axis model to examine individual plant harvest index in four grain legumes. Annals of Botany 94: 385-392.

33. Siddique, K.H.M. \& Loss, S.P. 1996. Growth and seed yield of vetches (Vicia spp.) in south-western Australia. Australian Journal of Experimental Agriculture 36: 587-93

34. Chin, C.M. \& Wahid, M.B. 2007. Biomass resources from the Malaysian palm oil industry. 15th European Biomass Conference \& Exhibition, 7-11 May 2007, Berlin, Germany (OC7.1) p. 62-65.

35. Ho, K. 2006. The potential of bagasse-based cogeneration in the US. Columbia University. http://www.columbia. edu/ kjh2103/US-Bagasse-Cogen-Potential.pdf. Cited on 3.9.2009.

36. Jölli, D. \& Giljum, S. 2005. Unused biomass extraction in agriculture, forestry and fishery. SERI-Studies 3, Sustainable Europe Research Institute (SERI), Vienna, Austria.

37. Min, L.H. 1990. Sweet potato varietal trial. ARC Training Report, 4 p. http://www.arc-avrdc.org/pdf_files/ Lihongmin(8-N).pdf . Cited on 3.9.2009.

38. Holland, B., Welch, A.A., Unwin, I.D., Buss, D.H., Paul, A.A. \& Southgate, D.A.T. 1991. McCance and Widdowson's The composition of foods, 5th edition, Royal Society of Chemistry, Cambridge, UK.

39. Fineli ${ }^{\circledR}$ - Finnish Food Composition Database Vol. 8. Helsinki 2007. http://www.fineli.fi/index.php?lang=en. Cited on 3.9.2009.

40. Pate, F.M. 1981. Fresh chopped sugar cane in growing - finishing steer diets. Journal of Animal Science 53: 881888. http://jas.fass.org. Cited on 3.9.2009.

41. Juurikassarka 2005. Sokerijuurikkaan viljely- ja satotietoja. Juurikassarka 2005, 1: 12.

42. Official Statistics Sweden. 2008. Production of cereals, dried pulses, oilseed crops, potatoes and temporary grasses in 2007. Final statistics. JO 16 SM 0801. http://www. scb.se/Pages/PublishingCalendarViewInfo____259924. aspx?PublObjld=8507. Cited on 3.9.2009.

43. Commission Regulation (EC) No 687/2008 of 18 July 2008 establishing procedures for the taking-over of cereals by intervention agencies or paying agencies and laying down methods of analysis for determining the quality of cereals. Official Journal of the European Union 192: 20-46.

44. Milbrandt, A. 2005. A geografic perspective on the current biomass resource availability in the United States. NREL Technical Report 560-39181, Appendix A.

45. Herbek,J.H., Bitzer, M.J. Soybean Production in Kentucky, Part V: Harvesting, drying, storage, and marketing, AGR-132, University of Kentucky Publications. http:// www.ca.uky.edu/agc/pubs/agr/agr132/agr132.htm. Cited on 3.9.2009.

46. Goenaga, R.J. \& Irizarry, H. 1994. Accumulation and partitioning of dry matter in water yam. Agronomy Journal 86: 1083-1087. 